UJMR, Volume 6 Number 1, June, 2021, pp 227 - 232

ISSN: 2616 - 0668

https://doi.org/10.47430/ujmr.2161.029

Received: $15^{\text {th }}$ June, 2021

Accepted: $30^{\text {th }}$ June, 2021

\title{
Potentials of Saccharomyces cerevisiae Y10 as a Starter Culture for Wine Production from Date Palm (Phoenix dactylifera) Fruits
}

\author{
${ }^{* 1}$ Adeleke A.J. (D), ${ }^{1}$ Ewansiha J.U. (D), ${ }^{2}$ Thomas B.T. and ${ }^{1}$ Shitu A.S. \\ ${ }^{1}$ Department of Microbiology, Modibbo Adama University, Yola, Nigeria. \\ ${ }^{2}$ Department of Microbiology, Olabisi Onabanjo University, Ago-Iwoye, Nigeria. \\ "Corresponding Author: lekejohnson2222@mautech.edu.ng; +2348060260571;
}

\begin{abstract}
A considerable quantity of agricultural produce in Nigeria gets spoilt due to lack of storage facilities and poor storage conditions. An example of such agricultural produce is date palm which is readily available in the northern parts of Nigeria. This study aimed at evaluating the potential of Saccharomyces cerevisiae $\mathrm{Y} 10$ isolated from decomposed sugarcane bagasse to produce wine using date palm fruits. The yeast was isolated using yeast extract peptone dextrose agar and was identified by molecular methods. Fermentation of date palm fruit juice was carried out anaerobically for 20 days during which physicochemical parameters and proximate composition were determined using standard methods. The yeast was identified as Saccharomyces cerevisiae Y10 with accession number MG321589. Analysis of physicochemical properties showed that pH dropped from 5.4 to 3.6 , titratable acidity increased from 0.25 to $0.71 \%$ and specific gravity decreased from 1.1 to 1.01 . Proximate composition of produced wine gave low total reducing sugar and low protein of 0.11 and $0.44 \%$ respectively and the final alcohol content was $10.4 \%$ at the 20th day of fermentation. This study has shown that Saccharomyces cerevisiae Y10 which was isolated from decaying sugarcane bagasse sample has the potential to be used as starter culture for fermentation of date palm for wine production.
\end{abstract}

Keywords: Date palm, Saccharomyces cerevisiae Y10, wine, yeast, alcoholic fermentation

\section{INTRODUCTION}

Wine is an alcoholic beverage often made of grape juice. Any fruit with good proportion of sugar may be used in producing wine and the resultant wine normally named after the fruit(Idise and Odum, 2011). Wine is produced by fermenting a crushed fruit using various types of yeast which consume the sugars found in the fruit and convert them into alcohol. Fruit juice is the major source of wine. Some wines such as barley wine and rice wine, for example, sake is made from starch-based materials. In these cases, the use of the term wine is referenced to the higher alcoholic content rather than production process (Saiko et al., 2009).

Phoenix dactylifera has long been one of the most important fruits in the arid region of Arabia, Peninsula, North Africa and Middle East (Krueger, 2007). During the past three centuries, date palm was also introduced to new production area in Australia, India, Mexico, Southern Africa and the United States. The fruit's Latin name dactifera comes from the Greek words "dactulos" for finger and "fera" for fruit because of the fruit's elongated shape. Dates fruits are oval-cylindrical, $3-7 \mathrm{~cm}$ long and $2-3 \mathrm{~cm}$ diameter. When unripe, the colour ranges from bright red to yellow in colour depending on the variety(Gbadamosi, 2010). Date palm is highly nutritious. It is rich in carbohydrate 70 - $80 \%$ comprising mainly of sugar and dietary fibres, making it one of the most nourishing natural foods available to man (Al-Yasiri et al., 2013). They are also a good source of vitamins and micro elements such as phosphorus, iron, potassium, and calcium. Besides the nutritious value, date palm is also rich in phenolics and flavonoids compounds which have been shown to possess biological benefits for human health. There was a report that dates were brought to Nigeria by pilgrims from the North Africa and it has become a widely grown and consumed fruit in the northern parts of Nigeria over the years. Majority of brands of wine consumed in Nigeria are imported and are not easily affordable by low-income Nigerians. Over dependence on imported products is generally not healthy for the growth of Nigerian economy and it is very essential that local technologies be developed towards attaining self-sustainability. However, large quantities of date fruits are disposed due to lack of adequate storage facilities resulting 
UJMR, Volume 6 Number 1, June, 2021, pp 227 - 232

in loss of nutrients and a potential source of Therefore, the aim of this study was to produce wine with date palm fruits using Saccharomyces cerevisiae isolated from decomposed sugarcane bagasse.

\section{MATERIALS AND METHODS}

Collection of samples

Visibly healthy-looking date palm fruits were purchased from the local market in Girei, Adamawa State of Nigeria and transported in a clean polythene container to the laboratory where it was stored at room temperature until use.

\section{Isolation and identification of yeast}

Yeast was isolated from asugarcane bagasse samples buried in the soil (depths of $8-12 \mathrm{~cm}$ ) on the campus of Modibbo Adama University of Technology, Yola, Adamawa State during a separate research aimed at isolating efficient ethanol producing yeasts from lignocellulosic materials. The bagasse was left in the soil to undergo degradation for three months before isolation. Serial dilution method was employed for isolation. Seven test tubes labelled 1 to 7 were used. Ten gram $(10 \mathrm{~g})$ of buried sugarcane bagasse sample was weighed into $90 \quad \mathrm{ml}$ of sterile distilled water in tube 1 and shaken thoroughly to make $10^{-1}$. Dilutions were subsequently made up to $10^{-6}$. Inoculation was done under the laminar flow cabinet using the pour plate technique. One milliliter of $10^{-6}$ dilution was placed in sterile petri dish and $15 \mathrm{ml}$ of sterilized media added and allowed to solidify. Streptomycin $(100 \mu \mathrm{g} / \mathrm{l})$ was added to the media. YEPD, after sterilization before use to prevent bacterial growth. Propionic acid supplement was also added to YEPD to inhibit the growth of molds. The inoculated Agar medium was incubated for forty-eight (48) hours at $30^{\circ} \mathrm{C}$. Microscopic examination of the isolate was carried out using wet mount method. Molecular identification of isolates was performed using sequence data of the Internal Transcribed Spacer (ITS) region of the nuclear ribosomal DNA. Isolated DNA was used as template for PCR amplification of the ITS region using primers: NS1(5GTAGTCATATGCTTGTCTC-3) and NS8 (5TCCGCAGGTTCACCTACGGA-3). Amplified fragments were sequenced, and sequences compared with those of reference strains in database (GenBank).

Production of date fruit wine

Date palm fruits were cleaned with distilled water to remove contaminants and allowed to air dry. The pulp was cut, and seed removed. revenue.

The pulp was crushed to powder with a sterile grinding machine to increase the surface area for fermentation. After grinding, $200 \mathrm{~g}$ of crushed date palm fruits was introduced into 1 $L$ of hot water to extract the juice. Thereafter, it was sieved and squeezed tightly using a sterile muslin cloth. Juice extraction process was repeated on the residual pulp using $500 \mathrm{ml}$ of hot water. The filtrate was then turned into a glass jar and then pasteurized at $80^{\circ} \mathrm{C}$ for 20 minutes. Inoculation was done by adding $150 \mathrm{ml}$ of standardized standard culture of approximately $6.0 \log 10 \mathrm{CFU} / \mathrm{ml}$. Fermentation was carried out at room temperature for 20 days with manual shaking once every 24 hours. To prevent explosion due to release of carbon dioxide during fermentation, an air trap was fixed to the fermentation glass jar. For comparison, yeasts reactivated from a commercial brewer's yeast was also used as starter culture in a similar experiment. Fermentation was terminated by pasteurizing the wine at $60^{\circ} \mathrm{C}$ for 15 minutes. Wine was left for 10 hours to allow the yeasts to flocculate after which the clarified wine, that is, the supernatant was siphoned into a sterilized glass jar and allowed to age for 55 days. Microbial analysis was carried out on pasteurized fruit juice samples taken before the commencement of fermentation and wine samples taken shortly before fermentation was terminated on the 20th day by plating the samples on PDA and nutrient Agar.

Measurement of specific gravity, $\mathrm{pH}$, titratable acidity and percentage total sugar The $\mathrm{pH}$ was determined using Kent EIL 7020 model $\mathrm{pH}$ meter. The titratable acidity was determined by titrating $10 \mathrm{ml}$ of sample with $0.1 \mathrm{M}$ of sodium hydroxide using 3 drops of phenolphthalein as $\mathrm{pH}$ indicator. Noting the volume of $\mathrm{NaOH}$ used for the titration, the titratable acidity (TA) was calculated using TA $=$ (volume of $\mathrm{NaOH} /$ volume of sample) $\times 0.75$ (Mohammed, et al. 2018).

Percentage reducing sugar concentration was determined using the 3,5-dinitrosalicylic acid (DNS) assays (Miller, 1959) and measuring the absorbance of the sample solution at $540 \mathrm{~nm}$ using a spectrophotometer (Lamda $25 \mathrm{UV} / \mathrm{Vis}$ Spectrophotometer). Specific gravity was determined with a refractometer by adding 2 drops of the sample on the glass prism and the values taken from the calibration by looking through the lens (Awe and Nnadoze, 2015). Alcohol content of must was assayed using the triple scale hydrometer. A sterile glass test jar was filled up to $3 / 4$ with the sample and the hydrometer was introduced to float on the jar. Readings were taken from the potential alcohol 
UJMR, Volume 6 Number 1, June, 2021, pp 227 - $232 \quad$ ISSN: 2616 - 0668

scale of the hydrometer and alcohol content was estimated by subtracting the final reading from the initial reading. Measurements were Sensory evaluation

Sensory evaluation for general acceptability of produced wine from $\mathrm{S}$. cerevisiae $\mathrm{Y} 10$ and the commercial brewer's yeast was done after allowing the wine to age for 55 days using ten judges according to Awe and Nnadoze, (2015).

\section{Statistical analysis}

Data were analyzed using one way ANOVA followed by Duncan multivariable post-hoc test to compare between the wine samples produced. $\mathrm{P}$ values less than 0.05 were considered statistically significant.

\section{RESULTS AND DISCUSSION}

The morphology of the yeast cells was observed on the culture plates and under the microscope. The isolate was observed to be flat with smooth edges, moist, creamy and glistening in appearance and were circular in shape. Budding was also observed. The gel electrophoresis micrograph of the amplified product is shown in Plate 1. After a BLAST search through the GenBank of National Center for Biotechnology Information (NCBI), it was found that the genetic sequence of the $18 \mathrm{~S}$ rDNA of the isolate $X Y$ had $100 \%$ similarity with Saccharomyces cerevisiae strain FJU-YS5 and so it was identified as Saccharomyces cerevisiae Y10 (Figure 1).

The statistical evaluation of each of the physicochemical parameters of the commercial brewer's yeast were carried out relative to that of the test organism S. cerevisiae Y10 from day 0 through day 5 to day 20. As shown in table 1 , no significant variation was observed in the activities of both $S$. cerevisiae strain $\mathrm{YIO}$ and the brewer's yeast. The initial $\mathrm{pH}$ which was 5.4 before the commencement of fermentation gradually dropped to 3.58 and 3.6 in brewer's yeast and S. cerevisiae Y10 respectively. The titratable acidity increased from 0.25 to 0.7 and 0.71 in brewer's yeast and S. cerevisiae $\mathrm{Y} 10$ respectively. The decrease in $\mathrm{pH}$ and the increase in the titratable acidity is an indication of accumulation of acids due to yeast metabolism (Awe and Nnadoze, 2015). This observation is important in wine production as low $\mathrm{pH}$ can inhibit the growth of unwanted organisms during the fermentation process but promotes good environmental conditions for taken over a period of 20 days at five days interval.

the desired organisms (Reddy and Reddy 2009; Mohammed, et al. 2018). Microbial contamination was not observed in this study as juice and wine samples analyzed did not show presence of fungi and bacteria. This was probably because of pasteurization of the must as also reported by Mohammed et al. (2018) and Balogu and Towobola (2017). Specific gravity decreased in both cases from 1.1 to about 1 within the 20 days of fermentation. Averagely, the sugar content of the must was depleted within the first 10 days of fermentation in both cases. At the end of the 20 days fermentation, alcohol content was observed to be $10.3 \%$ and $10.4 \%$ in brewer's yeast and S. cerevisiae $\mathrm{Y} 10$ respectively. This is no significant difference between the two. The reduction in specific gravity and sugar over the fermentation period shows that the yeasts were able to utilize the sugar content of the must and hence, an increase in the alcohol content. This agrees with the explanation given by Oladoja, et al. (2021).

Table 2 shows the proximate composition of date palm fruit juice and wine samples. The raw date palm fruit juice has total reducing sugar, protein, ash content, crude fat and moisture of $20.52 \%, 2.46 \%, 4.56 \%, 0.64 \%$ and $76.65 \%$ respectively. After fermentation and ageing, there was a significant difference in the proximate composition. The low protein content in the fruit juice before fermentation which was also observed to be much lower after ageing can be submitted to be a positive development as such could be an indication that the fear of over-accumulation of protein due to consumption of the fruits do not come to play (Okegbile and Taiwo, 2009).

The overall percentage acceptability level of the produced by the two starter cultures are presented in Figure 2. Date wine fermented by S. cerevisiae Y10 had $85 \%$ acceptability while that fermented by brewer's yeast had $85.6 \%$. This implies that the yeast strain $\mathrm{S}$. cerevisiae Y10 compares well with the commercial brewer's yeast used in this study and therefore can be considered for commercialization as brewer's yeast for both home and industrial brewery. 


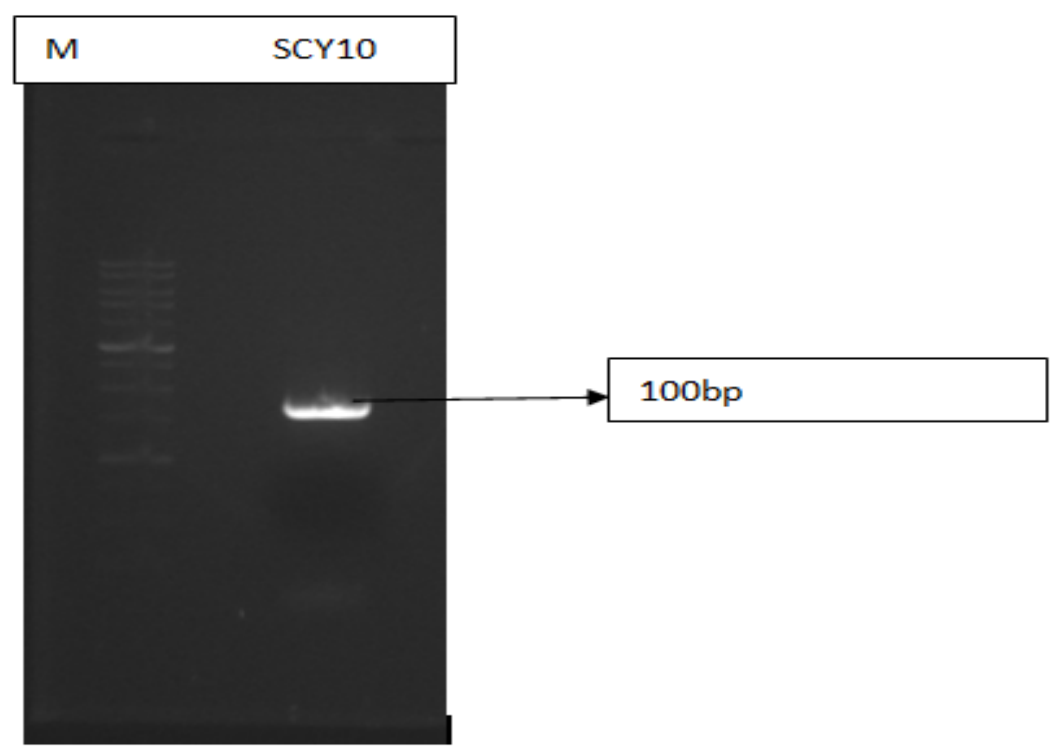

$\mathrm{M}=$ Marker DNA

SCY10 = Saccharomyces cerevisiae Y10

Plate 1. Molecular DNA amplification of S. cerevisiae Y10

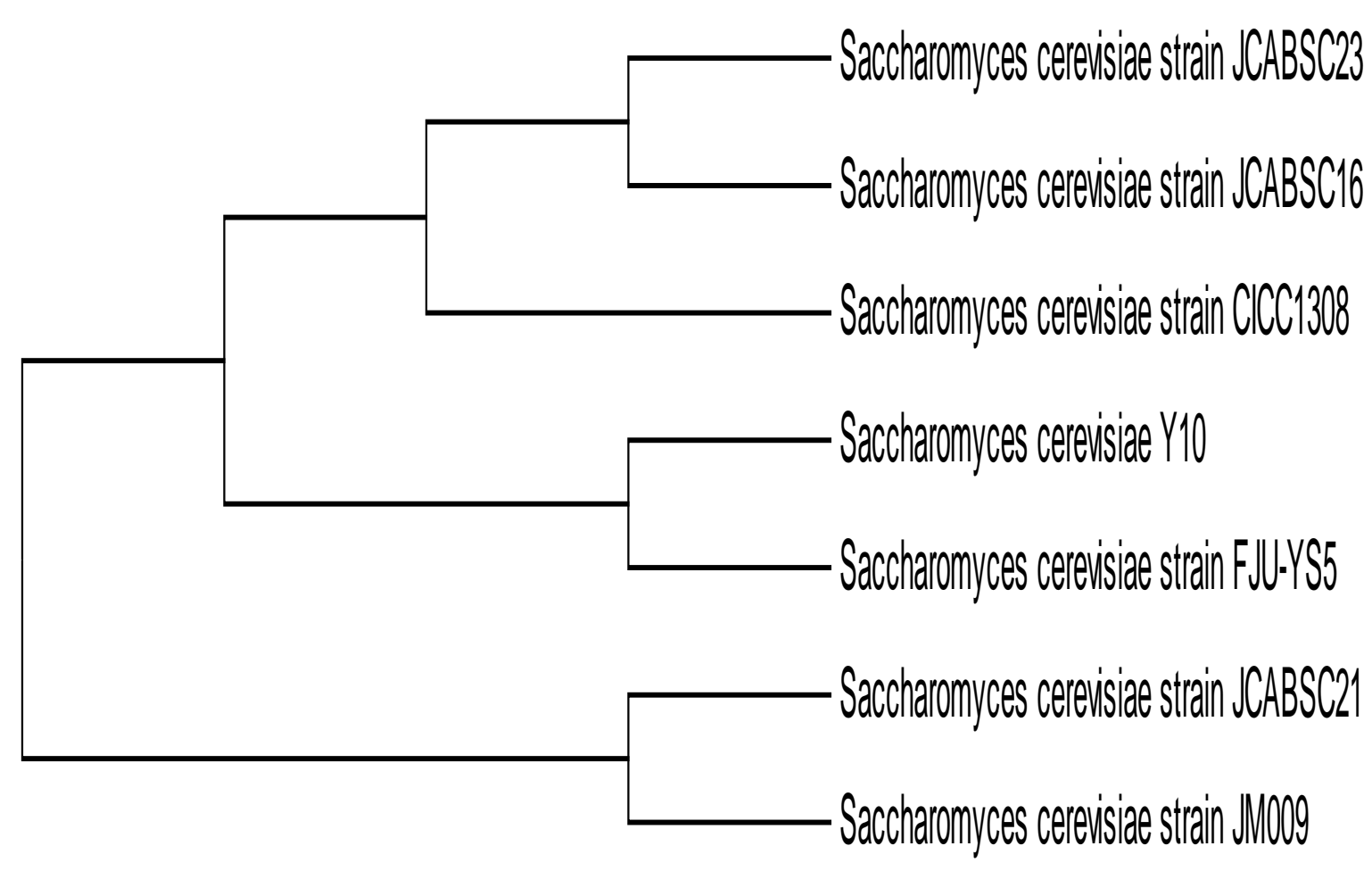

Figure 1: The phylogenetic tree of Saccharomyces cerevisiae Y10 (MG321589) based on the 18S rDNA sequence comparison of related isolates 
Table 1: Physicochemical analysis of must during anaerobic fermentation

\begin{tabular}{|c|c|c|c|c|c|c|c|c|c|c|}
\hline \multirow{2}{*}{$\begin{array}{l}\text { Fermentation } \\
\text { Time (days) }\end{array}$} & \multicolumn{2}{|c|}{$\mathrm{pH}$} & \multicolumn{2}{|c|}{ \% Sugar } & \multicolumn{2}{|c|}{ Specific gravity } & \multicolumn{2}{|c|}{ Titratable Acidity } & \multicolumn{2}{|c|}{ \% Alcohol } \\
\hline & $\begin{array}{l}\text { Baker's } \\
\text { yeast }\end{array}$ & $\begin{array}{l}\text { S. } \\
\text { cerevisiae } \\
\text { Y10 }\end{array}$ & $\begin{array}{l}\text { Brewer's } \\
\text { yeast }\end{array}$ & $\begin{array}{l}\text { S. } \\
\text { cerevisiae } \\
\text { Y10 }\end{array}$ & $\begin{array}{l}\text { Brewer's } \\
\text { yeast }\end{array}$ & $\begin{array}{l}\text { S. } \\
\text { cerevisiae } \\
\text { Y10 }\end{array}$ & $\begin{array}{l}\text { Brewer's } \\
\text { yeast }\end{array}$ & $\begin{array}{l}\text { S. } \\
\text { cerevisiae } \\
\text { Y10 }\end{array}$ & $\begin{array}{l}\text { Brewer's } \\
\text { yeast }\end{array}$ & $\begin{array}{l}\text { S. } \\
\text { cerevisiae } \\
\text { Y10 }\end{array}$ \\
\hline 0 & $5.40 \pm 0.20^{\mathrm{a}}$ & $5.40 \pm 0.00^{\mathrm{a}}$ & $20.52 \pm 0.00^{a}$ & $20.52 \pm 0.01^{a}$ & $1.10 \pm 0.00^{a}$ & $1.10 \pm 0.01^{\mathrm{a}}$ & $0.25 \pm 0.01^{a}$ & $0.25 \pm 0.01^{a}$ & $0.00 \pm 0.00^{\mathrm{a}}$ & $0.00 \pm 0.00^{a}$ \\
\hline 5 & $4.87 \pm 0.10^{\mathrm{b}}$ & $4.90 \pm 0.01^{b}$ & $4.51 \pm 0.00^{\mathrm{b}}$ & $4.42 \pm 0.01^{\mathrm{b}}$ & $1.05 \pm 0.00^{b}$ & $1.04 \pm 0.01^{b}$ & $0.58 \pm 0.02^{b}$ & $0.58 \pm 0.01^{b}$ & $5.38 \pm 0.02^{b}$ & $5.40 \pm 0.00^{\mathrm{b}}$ \\
\hline 10 & $4.60 \pm 0.05^{c}$ & $4.60 \pm 0.01^{c}$ & $1.20 \pm 0.20^{c}$ & $0.00 \pm 0.00^{c}$ & $1.02 \pm 0.00^{c}$ & $1.02 \pm 0.01^{c}$ & $0.65 \pm 0.00^{c}$ & $0.64 \pm 0.00^{c}$ & $6.81 \pm 0.01^{c}$ & $6.80 \pm 0.00^{c}$ \\
\hline 15 & $3.76 \pm 0.50^{d}$ & $3.90 \pm 0.05^{d}$ & $0.00 \pm 0.20^{d}$ & $0.00 \pm 0.00^{c}$ & $1.02 \pm 0.00^{c}$ & $1.01 \pm 0.00^{c}$ & $0.68 \pm 0.02^{d}$ & $0.69 \pm 0.00^{d}$ & $8.77 \pm 0.00^{d}$ & $8.80 \pm 0.01^{d}$ \\
\hline 20 & $3.58 \pm 0.09$ & $3.60 \pm 0.04^{e}$ & $0.00 \pm 0.20^{d}$ & $0.00 \pm 0.00^{c}$ & $1.00 \pm 0.00^{c}$ & $1.01 \pm 0.00^{c}$ & $0.70 \pm 0.01^{e}$ & $0.71 \pm 0.00^{d}$ & $10.3 \pm 0.01^{e}$ & $10.40 \pm 0.03^{e}$ \\
\hline
\end{tabular}

Parameters with the same superscripts are not statistically different $\left({ }^{a}\right)$

Table 2: Proximate composition of date palm fruit juice and wine samples

\begin{tabular}{|c|c|c|c|}
\hline \multirow[b]{2}{*}{ Parameters } & \multicolumn{3}{|c|}{ Proximate composition (\%) } \\
\hline & Date palm fruit & $\begin{array}{l}\text { Date palm wine } \\
\text { by } Y 10\end{array}$ & $\begin{array}{l}\text { Date palm wine } \\
\text { by brewer's } \\
\text { yeast }\end{array}$ \\
\hline $\begin{array}{l}\text { Total reducing sugar } \\
(\%)\end{array}$ & $20.52 \pm 0.01^{a}$ & $0.11 \pm 0.12^{b}$ & $0.12 \pm 0.00^{\mathrm{b}}$ \\
\hline Protein $(\%)$ & $2.46 \pm 0.00^{a}$ & $0.44 \pm 0.00^{b}$ & $0.47 \pm 0.00^{\mathrm{b}}$ \\
\hline Ash content (\%) & $4.56 \pm 0.00^{a}$ & $0.02 \pm 0.00^{\mathrm{b}}$ & $0.03 \pm 0.00^{b}$ \\
\hline Crude fat (\%) & $0.64 \pm 0.00^{a}$ & ND & ND \\
\hline Moisture content (\%) & $76.65 \pm 0.10^{a}$ & $86.42 \pm 0.14^{b}$ & $86.46 \pm 0.00^{\mathrm{b}}$ \\
\hline
\end{tabular}

Key: ND $=$ Not Detected, parameters with the same superscripts are not statistically different $\left({ }^{a}\right)$ 


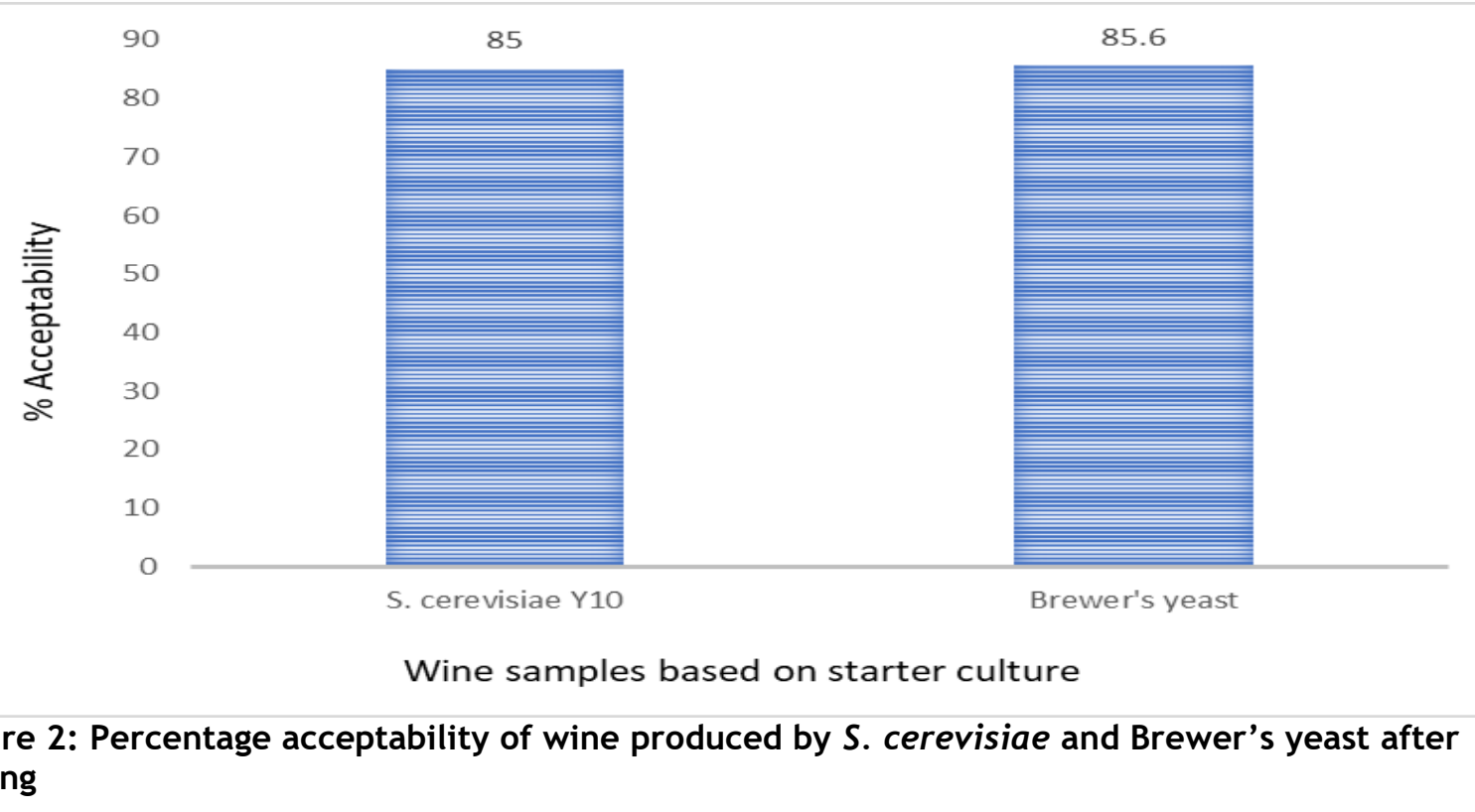

\section{CONCLUSION}

Saccharomyces cerevisiae Y10 which was isolated from decaying sugarcane bagasse sample was used to ferment date palm juice. The wine produced had high acceptability with alcohol content of $10.4 \%$ at 20th day of fermentation.

\section{REFERENCES}

Al-Yasiri, T. H., Meyada, F. M., \& Firase, M. H. (2013). effect of adding different level of date flesh (Phoenix dactyliphera) to ratio containing probiotic on brioler chickens reared under heart stress. 306-311.

Awe, S., \& Nnadoze , S. N. (2015). Production and microbiological assessment of date palm Phoenix dactylifera L. fruit wine. British Microbiology Research journal, 8(3), 480488.

Balogu, T. V., \& Towobola, O. (2017). Production and quality analysis of wine from honey and coconut milk blend using Saccharomyces cerevisiae. Fermentation, 3(2), 16.

Gbadamosi, W. N. (2010). medicinal importance of date palm. Date Palm Fruit, 2, 70-85.

Idise, O. E., \& Odum, E. I. (2011). Studies of wine produced from banana. International Journal for Biotechnology and Molecular Biology Research, 2(12), 209-214.

Krueger, R. R. (2007). Nutritional dynamics of date palm Phoenix dactylifera L. Acta Hort, 736, 177-186.

Miller, G.L. (1959). Use of dinitrosalicylic acid reagent for determination of reducing sugars. Analytical Chemistry, 31: 426 - 428.

Mohammed, S. S., Yohanna, B., Wartu, J. R., Abubakar, N. L., \& Bello, S. (2018). Wine
This study therefore shows that $\mathrm{S}$. cerevisiae Y10has the potential to be used as starter culture for both domestic and industrial fermentation of date palm, a readily available fruit in Nigeria, to produce wine.

produced from fermentation of honey slurry and dates palm fruit juice blend using Saccharomyces cerevisiae isolated from palm wine. International Journal of Biology, 10(3), 52-61.

Okegbile, E. O., \& Taiwo, E. A. (2009). The nutritional potential of black velvet. Nigerian Journal of Nutrition Science, 115121.

Oladoja, E. O., Oyewole, O. A., Okeke, S. K., Azuh, V. O., Oladoja, O. I., \& Jagaba, A. (2021). Wine production from date palm (Phoenix dactylifera L.) fruits using Saccharomyces cerevisiae X01 isolated from Nigerian locally fermented beverages. Archives of Microbiology, 203, 193-204.

Saiko, P., Szakmary, A., Szekeres, T., Filipic, M., Plazar J. \&Arimoto-Kobayashi S. (2009). Protective Effects of Alcoholic Beverages and their Constituent. In: Chemoprevention of Cancer and DNA Damage by Dietary Factors. New Jersey: Wiley-Blackwell. Pp. $635-661$

Reddy, L. V., \& Reddy, O. V. (2009). Production and optimization and characterization of wine from mango. Natural Product Journal, 426435. 